\title{
A social work study on different factors influencing youth on hope for the future
}

\author{
Akram Fakhri Fakhramini ${ }^{a^{*}}$, Mohammad Reza Iravani ${ }^{\mathrm{b}}$, Mostafa Rajabi ${ }^{\mathrm{c}}$, Ahmad Masaeli ${ }^{\mathrm{d}}$ and Hajar \\ Jannesari $^{\mathrm{e}}$
}

${ }^{a}$ MA Student, Department of Sociology, Dehaghan Branch, Islamic Azad University, Isfahan, Iran

${ }^{b}$ Assistant Professor, Department of Social Work, Islamic Azad University Khomeinishahr Branch, Daneshjou Blvd, Iran

${ }^{c}$ Assistant Professor, Department of Economic, Islamic Azad University of Khomeinishahr, Islamic Azad University Khomeinishahr Branch, Daneshjou Blvd, Iran

${ }^{d}$ Islamic Azad University of Khomeinishahr, Department of Human Science, Khomeinishahr Branch, Daneshjou Blvd, Iran

${ }^{e}$ MS Student, Counseling Department, Islamic Azad University of Khomeinishahr, Khomeinishahr Branch, Daneshjou Blvd, Iran

\section{H R O N I C L E A B S T R A C T}

Article history:

Received October 14, 2012

Received in revised format

5 February 2012

Accepted 7 February 2013

Available online

February 72013

Keywords:

Leadership style

Educational system

Laissez-fair leadership

Transactional leadership

\begin{abstract}
In this paper, we present an empirical study to study the effects of religious duties, communicating with parents; leisure, media planning, city planning, socio-economic and education on different factors influencing the future of youth. The proposed study of this paper designs a questionnaire and distributes it among 400 people aged 18 to 29 and the results are investigated using Pearson correlation ratios. The results of our investigation indicate that there are some positive and meaningful relationship between religious duties and their hope for future $(\mathrm{r}=44 \%$ ), a positive and meaningful relationship between leisure and hope for future (31\%). In addition, there is a relatively positive and somewhat meaningful relationship between city planning and hope for future (15\%) and finally, a small but positive relationship between media planning and hope for the future (6\%). However, there is no evidence belief that there is any meaningful relationship between education and hope for the future.
\end{abstract}

\section{Introduction}

Young people are those who are supposed to build our future, they are the primary source of human resource development and they will be responsible to take care of older generation (Wheatley, 2002; Rorty, 2002; Wennberg \& Wennberg, 2003). There has been a growing interest in the youth and family mental health treatment literature on the implementation of empirically supported treatments (ESTs). There have been also some interests on universal aspects of the therapy process, which may have some impact on therapy outcomes. It is also more likely that the success of the methods proposed by ESTs may depend on the presence of common process factors. Hicks, D. (1996) explored the relative importance of recent studies into popular images of the future. He began by reviewing the main literature on adults' and young people's views of the future and then went on to

*Corresponding author. Tel: + 989133180083

E-mail addresses: amini.sahar1@gmail.com. (A. Fakhri) 
describe the findings of a recent UK research project by investigating how 7-18-year-old could see the future at personal, local and global scales. Karver et al. (2005) explored the status of common process factors in the youth and family therapy literature, and proposed a theoretical framework linking specific therapeutic relationship variables and treatment outcomes for children and adolescents. Elliott et al. (1999) investigated different factors affecting educational motivation by performing a comprehensive study of attitudes and behavior of children in Sunderland, Kentucky and St Petersburg and found similar results to Brendtro et al. (1990) Peterson and Seligman (2004).

Raffaelli and Koller (2005) examined future expectations of youth surviving on the streets of Porto Alegre, Brasil, by looking into a sample of 35 boys and 34 girls aged 10-18 ( $\mathrm{M}$ age 14.4) who participated in a sentence completion task and semi-structured interviews. Responses to two incomplete sentences regarding the future disclosed a mismatch between hoped-for and expected events. When completing the sentence, "In the future, I hope..." the majority of youth gave optimistic (but generally non-specific) responses. In contrast, the sentence "For me, the future..." elicited more pessimistic responses. They suggested that life on the street shapes and constrains how youth see their futures. Murphey et al. (2004) investigated the relationships of a brief measure of youth assets to health-promoting and risk behaviors and concluded that Students' assets, even if relatively few, may make important contributions to wellness, independent of other well-established demographic factors. Ssewamala et al. (2012) explained that youth of color were disproportionately likely to grow-up in poor, disadvantaged neighborhoods characterized by high levels of psychosocial stressors and inadequate supportive resources. They explained that poverty and racial minority status could correlate with an increased risk of high-school dropout, teen pregnancy, substance abuse, and sexually transmitted infections (STIs) and performed a qualitative study that studied the feasibility and acceptability of an economic empowerment intervention in the South Bronx and East Harlem.

In this paper, we present an empirical study to study the effects of religious duties, communicating with parents; leisure, media planning, city planning, socio-economic and education on different factors influencing the future of youth. The organization of this paper first presents details of the proposed study in section 2 while section 3 studis th rsults of our survey and finally concluding remarks are given in the last to summarizes the contribution of the paper.

\section{The proposed study}

In this paper, we present an empirical study to study the effects of religious duties, communicating with parents; leisure, media planning, city planning, socio-economic and education on different factors influencing the future of youth in province of Esfahan, Iran. The study selects a sample of 400 people aged 18 to 29 and the results are investigated using Pearson correlation ratios. Fig. 1 demonstrates some basic characteristics of the people who participated in our survey.

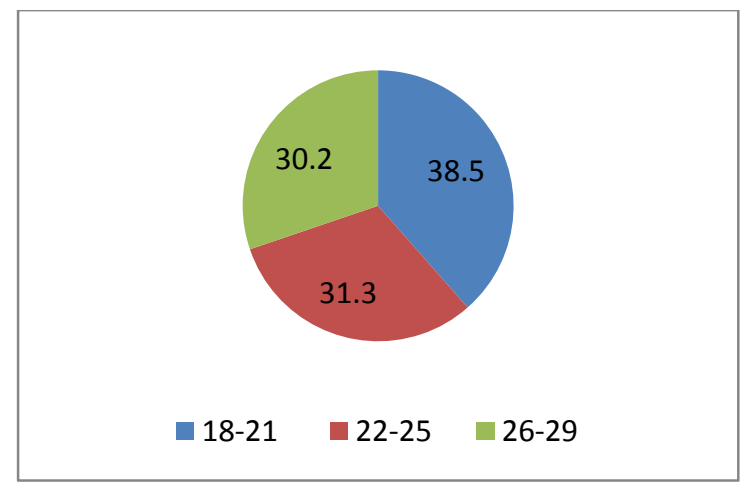

Fig. 1(a) Age

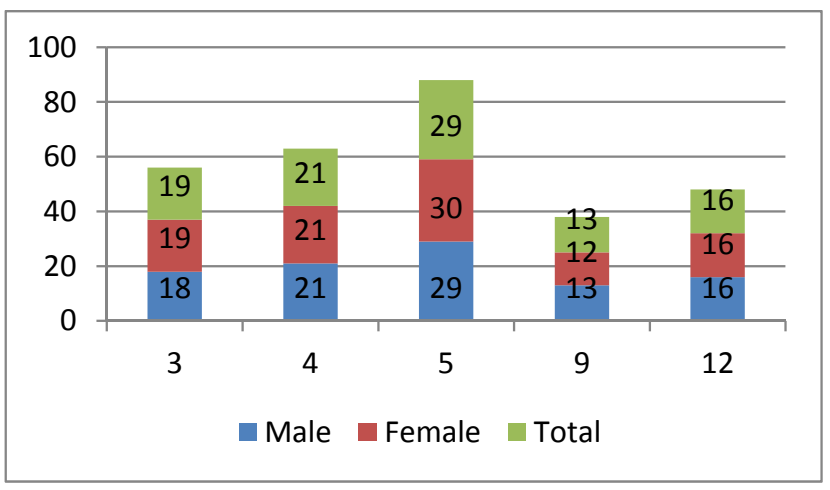

Fig. 1(b) Gender in different regions

Fig. 1. Personal characteristics of the participants 
The proposed study of this paper has been implemented in different regions of 3, 4, 5, 9 and 12 and all questions were arranged in Likert scale. In our survey, $35.2 \%$ of the participants only managed to finish high school, $18 \%$ hold a 2-year college, 36.5\% of the participants hold bachelor degree of science, 9.1\% hold master degree of science and 1.3\% hold PhD. We have studied the effects of religious duties, communicating with parents; leisure, media planning, city planning, socio-economic and education on different factors influencing the future of youth. We use Pearson correlation ratio to test the hypotheses and the results are presented next.

\section{The results}

\subsection{The first hypothesis: Religious duties and hope for future}

The first hypothesis of this survey is associated with the relationship between Religious duties and hope for future. Table 1 shows details of our findings,

\section{Table 1}

The results of Pearson correlation test between Religious duties and hope for future

\begin{tabular}{lcl}
\hline Resource & $\mathrm{R}$ & $\mathrm{P}$-value \\
\hline Religious duties and hope for future & 0.44 & 0.00 \\
\hline
\end{tabular}

As we can observe from the results of Table 1, there is a positive and meaningful relationship between these two components and we can conclude that practicing religious duties influences positively on hope for future.

\subsection{The second hypothesis: Leisure and hope for future}

The second hypothesis of this survey is associated with the relationship between leisure and hope for future. Table 2 demonstrates details of our findings,

Table 2

The results of Pearson correlation test between leisure and hope for future

\begin{tabular}{lcl}
\hline Resource & $\mathrm{R}$ & $\mathrm{P}$-value \\
\hline Leisure and hope for future & 0.31 & 0.02 \\
\hline
\end{tabular}

As we can observe from the results of Table 2, there is a positive and meaningful relationship between these two components and we can conclude that leisure plays an important role on hope for future. This could motivate more municipality of the city for planning better equipment for youth.

\subsubsection{The first sub-hypothesis of the second hypothesis: Cultural leisure and hope for future}

The first sub-hypothesis of the second hypothesis of this survey is associated with the relationship between cultural leisure and hope for future. Table 3 demonstrates details of our findings,

\section{Table 3}

The results of Pearson correlation test between cultural leisure and hope for future

\begin{tabular}{lcl}
\hline Resource & $\mathrm{R}$ & $\mathrm{P}$-value \\
\hline Cultural leisure and hope for future & 0.42 & 0.03
\end{tabular}

As we can observe from the results of Table 3, there is a positive and meaningful relationship between these two components and we can conclude that cultural leisure is an essential factor for increasing hope for future. 
3.2.2. The second sub-hypothesis of the second hypothesis: Entertainment leisure and hope for future

The second sub-hypothesis of the second hypothesis of this survey is associated with the relationship between entertainment leisure and hope for future. Table 4 demonstrates details of our findings,

\section{Table 4}

The results of Pearson correlation test between entertainment leisure and hope for future

\begin{tabular}{lcl}
\hline Resource & $\mathrm{R}$ & $\mathrm{P}$-value \\
\hline Entertainment leisure and hope for future & 0.20 & 0.00 \\
\hline
\end{tabular}

As we can observe from the results of Table 4, there is a positive and meaningful relationship between these two components and we can conclude that entertainment leisure is an essential factor for increasing hope for future.

\subsection{The third hypothesis: City planning and hope for future}

The third hypothesis of this survey is associated with the relationship between city planning issues and hope for future. Table 5 demonstrates details of our results,

\section{Table 5}

The results of Pearson correlation test between city planning issues and hope for future

\begin{tabular}{lcl}
\hline Resource & $\mathrm{R}$ & $\mathrm{P}$-value \\
\hline city planning issues and hope for future & 0.15 & 0.04 \\
\hline
\end{tabular}

As we can observe from the results of Table 5, there is a relatively positive and meaningful relationship between these two components and we can conclude that city planning issues are important on increasing hope for future.

\subsection{The fourth hypothesis: Media planning and hope for future}

The fourth hypothesis of this survey is associated with the relationship between media planning factors and hope for future. Table 6 demonstrates details of our results,

\section{Table 6}

The results of Pearson correlation test between media planning factors and hope for future

\begin{tabular}{lcl}
\hline Resource & $\mathrm{R}$ & $\mathrm{P}$-value \\
\hline Media planning factors and hope for future & 0.21 & 0.06 \\
\hline
\end{tabular}

As we can observe from the results of Table 6, there is not any meaningful relationship between these two components and we cannot conclude that media planning factors are important role on hope for future.

As we can observe, all factors influence hope for future and we need to use Freedman test to rank them based on their relative importance. The results indicate that the performance of city officials is ranked first (3.71), followed by leisure issues (3.49), hope for future (3.49), performance of media (3.43) and performing religious duties (3.35). We have also performed ANOVA test to see the effects of educational backgrounds in different regions of city and Table 7 summarizes the results of our survey. The results of Table 7 clearly show that there was no difference between different groups in terms of educational background. In other words, educational background did not play an important role for hope for future. 
Table 7

The results of ANOVA test on the effect of educational background on different regions

\begin{tabular}{|c|c|c|c|c|c|c|}
\hline Variable & & Sum of squares & $\mathrm{df}$ & Mean squares & $\mathrm{F}$ & P-Value \\
\hline \multirow{3}{*}{ City officials } & Between group & .442 & 4 & .110 & \multirow[t]{3}{*}{.206} & \multirow[t]{3}{*}{.235} \\
\hline & Inside group & 203.221 & 379 & .536 & & \\
\hline & Total & 203.663 & 383 & & & \\
\hline \multirow{3}{*}{ Media performance } & Between group & .280 & 4 & .070 & \multirow[t]{3}{*}{.166} & \multirow[t]{3}{*}{.155} \\
\hline & Inside group & 159.333 & 379 & .420 & & \\
\hline & Total & 159.613 & 383 & & & \\
\hline \multirow{3}{*}{ Leisure time } & Between group & 1.619 & 4 & .405 & \multirow[t]{3}{*}{.714} & \multirow[t]{3}{*}{.583} \\
\hline & Inside group & 214.727 & 379 & .567 & & \\
\hline & Total & 216.346 & 383 & & & \\
\hline \multirow{3}{*}{ Hope for future } & Between group & .655 & 4 & .164 & \multirow[t]{3}{*}{.606} & \multirow[t]{3}{*}{.749} \\
\hline & Inside group & 102.462 & 379 & .270 & & \\
\hline & Total & 103.117 & 383 & & & \\
\hline \multirow{3}{*}{ Religious duties } & Between group & .802 & 4 & .201 & \multirow[t]{3}{*}{.705} & \multirow[t]{3}{*}{.589} \\
\hline & Inside group & 107.862 & 379 & .285 & & \\
\hline & Total & 108.664 & 383 & & & \\
\hline
\end{tabular}

\section{Conclusion}

There is no doubt that young people are the most assets in any society since they are the people who sacrifice themselves for countries. These people need to have hope for better future so that they could be motivated to participate in society, actively. In this paper, we have presented an empirical study to investigate the effects of religious duties, communicating with parents; leisure, media planning, city planning, socio-economic and education on different factors influencing the future of youth. The results of our investigation indicate that there are some positive and meaningful relationship between religious duties and their hope for future ( $r=44 \%)$, a positive and meaningful relationship between leisure and hope for future (31\%). In addition, there is a relatively positive and somewhat meaningful relationship between city planning and hope for future (15\%) and finally, a small but positive relationship between media planning and hope for the future (6\%). However, there is no evidence belief that there is any meaningful relationship between education and hope for the future.

\section{References}

Brendtro, L. K., Brokenleg, M., \& Van Bockern, S. (1990). Reclaiming youth at risk: Our hope for the future. National Educational Service.

Elliott, J., Hufton, N., Hildreth, A., \& Illushin, L. (1999). Factors influencing educational motivation: a study of attitudes, expectations and behaviour of children in Sunderland, Kentucky and St Petersburg. British Educational Research Journal, 25(1), 75-94.

Karver, M. S., Handelsman, J. B., Fields, S., \& Bickman, L. (2005). A theoretical model of common process factors in youth and family therapy. Mental Health Services Research, 7(1), 35-51.

Hicks, D. (1996). A lesson for the future: Young people's hopes and fears for tomorrow. Futures, 28(1), 1-13.

Murphey, D.A., Lamonda, K.H., Carney, J.K., \& Duncan, P. (2004). Relationships of a brief measure of youth assets to health-promoting and risk behaviors. Journal of Adolescent Health, 34(3), 184191. 
Peterson, C., \& Seligman, M. E. P. (2004). Hope (optimism, future-mindedness, future orientation). C. Peterson \& ME Seligman, Character strengths and virtues: A handbook and classification, 569-582.

Raffaelli, M., \& Koller, S.H. (2005). Future expectations of Brasilian street youth. Journal of Adolescence, 28(2), 249-262

Rorty, R. (2002). Hope and the future. Peace Review, 14(2), 149-155.

Ssewamala, F.M., Sperber, E., Blake, C.A., \& Ilic, V.P. (2012). Increasing opportunities for innercity youth: The feasibility of an economic empowerment model in East Harlem and the South Bronx, New York. Children and Youth Services Review, 34(1), 218-224

Wennberg, D. E., \& Wennberg, J. E. (2003). Addressing variations: Is there hope for the future. Health Affairs, 22.

Wheatley, M. J. (2002). Turning to one another: Simple conversations to restore hope to the future. Berrett-Koehler Publishers. 